\title{
Fuzzy Multi Criteria Group Decision for Determining the Relative Importance of Critical Success Factors in Accounting Information Systems
}

\author{
DOI: $10.26466 /$ opus.869767
}

\author{
Rozi Mizrahi* - Berna Tektaş** - Aygülen Karakul*** \\ * Dr. Öğr. Üyesi, İzmir Kâtip Çelebi Üniversitesi, İ̈BF, İzmir/Turkiye \\ E-Posta: rozi.mizrahi@ikcu.edu.tr \\ ORCID: $0000-0001-7173-4456$ \\ ** Dr. Öğr. Üyesi, İzmir Kâtip Çelebi Üniversitesi, İïF, İzmir/Turkiye \\ E-Posta: berna.tektas@ikcu.edu.tr \\ ORCID: 0000-0002-0379-5916 \\ *** Dr. Öğr. Üyesi, İzmir Kâtip Çelebi Üniversitesi, İ̈BF, İzmir/Turkiye \\ E-Posta: aygulen.kayahan@ikcu.edu.tr \\ ORCID: $0000-0002-8310-1709$
}

\begin{abstract}
An effective Accounting Information System (AIS) will support the effectiveness of management functions in an enterprise. So, the aim of this research is to construct a prioritization-based taxonomy of critical success factors using fuzzy multi criteria group decision method: Fuzzy Group Analytical Hierarchy Process (FGAHP). In order to identify critical success factors of AIS, firstly, a deep literature survey was done. Then, a group of academic experts has been chosen from the accounting branch for pairwise comparison of critical success factors of AIS. After then, these chosen accounting experts evaluate the relative significance of critical success factors of the AIS which were defined from the literature. The results of the FGAHP analysis show that the most important success criteria of an AIS is the technological factors with weight $54 \%$, and the external factors are the least important main success criteria for an AIS with weight 9\%. Also, FGAHP evaluation of accounting experts decisions about sub criteria indicate that "security of knowledge" is the most important sub criteria with the weight $19 \%$, "software supporting systems" with weight $14 \%$ is the second important one, and. "RED activities and improvement" criteria with weight $8 \%$ is the third important sub criteria.
\end{abstract}

Key Words: $\quad$ Accounting Information Systems (AIS), Critical Success Factors, Multi Criteria Decision Making, Fuzzy AHP 
ISSN: 2528-9527

E-ISSN : 2528-9535

Yıl Year: 11

Cilt Volume: 17

Sayı Issue:37

Mayıs May 2021

Makalenin Geliş Tarihi Received Date. 28/01/2021 Makalenin Kabul Tarihi Accepted Date. 26/05/2021

\section{Bulanık Çok Kriterli Grup Kararı Verme Yöntemi ile Muhasebe Bilgi Sisteminde Kritik Başarı Faktörlerinin Göreceli Öneminin Belirlenmesi}

Öz

Etkili bir Muhasebe Bilgi Sistemi (MBS), bir kuruluştaki yönetim işlevlerinin etkinliğini destekleyecektir. Dolayısıyla, bu araştırmanın amacı, bulanık çok kriterli grup karar yöntemi: Bulanık Grup Analitik Hiyerarşi Süreci (FGAHP) kullanarak kritik başarı faktörlerinin önceliklendirmeye dayah bir taksonomisini oluşturmaktır. MBS'nin kritik başarı faktörlerini belirlemek için ilk olarak kapsamlı bir literatür taraması yapılmıştır. Ardından, MBS'nin kritik başarı faktörlerinin ikili olarak karşılaştırılması için muhasebe anabilim dalından bir grup akademik uzman seçilmiştir. Daha sonra, seçilen bu muhasebe uzmanları, literatürden tanımlanan MBS'nin kritik başar faktörlerinin göreceli önemini değerlendirmişlerdir. FGAHP analizinin sonuçları, bir MBS'nin en önemli ana başarı kriterinin \% 54 ağırlık ile teknolojik faktörler olduğunu ve \% 9 ağırlık ile bir MBS için dış faktörlerin en az önemli ana başarı kriterleri olduğunu göstermektedir. Ayrıca, muhasebe uzmanlarımın alt kriterlere ilişkin kararlarının FGAHP yöntemiyle değerlendirilmesine göre, \%19 ă̆ırlk ile "bilgi güvenliği" en önemlialt kriter, \%14 ağırlık ile "yazllım destek sistemleri" ikinci ve "Ar-Ge faaliyetleri" ise \%8 ağırlı ile üçüncü önemli alt kriterdir.

Anahtar Kelimeler: $\quad$ Muhasebe Bilgi Sistemi (MBS), Kritik Başarı Faktörleri, Çok Kriterli Karar Verme, Bulanık AHP. 


\section{Introduction}

Enterprises need qualified information in order to preserve their existence in the repetitive world of business life. Qualified information helps to make strategic decisions under uncertainty of markets and it is generated in the Accounting Information System (AIS) of the enterprise. In this sense the critical success factors of AIS must be examined in order to generate true and qualified information. In this research the critical success factors of AIS that is identified in the literature before, has been prioritized by using the advanced Multi Criteria Decision Method (MCDM) fuzzy Analytical Hierarchy Process (AHP) with a group decision of experts. The method Fuzzy AHP enables to handle the qualitative critical success factors of AIS and fuzziness enables to cope with vagueness of the experts. The defined relative weights of Critical Success Factors would help to enterprises to use the AIS more efficiently.

Fuzzy AHP with group decision is widely used method in MCDM problems. Büyüközkan and Feyzioğlu (2004) used fuzzy AHP in the new product development activities for enterprises Meixner (2009) used it for evaluation of energy sources, Sagedhi, Azar and Rad (2012) used fuzzy AHP to prioritize the factors affecting High technology SMEs in Iran, Jiao (2016) made a prioritization of risk evaluation of AIS with fuzzy AHP, Bahadır, Çebi, Kahraman and Kaloğlu (2013) used an integrated method of axiomatic design and fuzzy AHP for smart clothing system for blinds. Demircan-Keskin (2020) used Chang's algorithm on triangular fuzzy numbers in fuzzy AHP for resilient supply chain network design.

This paper is organized in five sections. In Sect.2 the conceptual framework is given, in Sect.3 methodology is explained in details, Sect.4 provides the results of application of Fuzzy AHP, finally, the conclusions are given in Sect.5.

\section{Conceptual Framework}

Having true and qualified information in an enterprise means to have power against the unknown and uncertain world. Information is an output that has been obtained after the processing operation and has an organized meaning and satisfies advantages to its users (Karagül, 2005, p.59-87). The importance 
of information for enterprises are not equal. Information must be true, relevant, complete, well timed, accessible, and confidential and cost effectively in order to be important for an enterprise (Çukacı, 2005, p.11-19).

AIS is a business information system that collects, keeps and redesign the data in order to convert it to information for internal and external stakeholders (Karahan,2020). The main function of the AIS is to generate information for the purpose of planning and developing the organizations as well as improving the operational and financial situation. In addition, the information that is generated by AIS are reported to the internal shareholders like managers and owners of the enterprise, also to the external shareholders like state and partners. So AIS has a vital role to prepare transparent, accountable and responsible financial reports since it is an effective management tool and helps to make true decisions by the system (Dinç and Abdioğlu, 2009, p.157184).

It is very important to identify and determine the relative weights of the critical success factors that affect the quality of information in AIS. The defined importance degree of critical success factors would guide to business managers to improve the quality of system and to generate qualified information.

Critical success factors are firstly defined by Rockart( 1979) from Massachusetts Institute of Technology in order to determine the information needs of top managers. Enterprises are effected by many internal and external factors. It is so difficult to examine all those factors. Instead, the critical success factors that affect the activities of enterprises must be determined since they directly influence the future of the enterprises (Ergin, 1997, p.8). Those factors are key areas to help to managers to reach to targets (Bullen and Rockart, 1981). The points that the managers focuses to conduct their enterprises perfectly are called critical success factors (Rockart, 1982: , p.).

In this study; AIS information quality factors determined by Acar and Özçelik( 2011) and Xu et all (2002) are grouped under four main titles of "Organizational Factors", "Intellectual Factors", "Technological Factors" and "External Factors".

Under the first main title of "Organizational Factors" 6 subgroups are constructed as institutionalization level, physical environment, flexibility of organization, senior management support, quality culture of organization and 
internal control system. Under "Intellectual factors" are 5 subgroups are constructed as education level, competency of staff, team work, loyalty to job, performance evaluation \& rewarding. Under the title of "Technological factors" 4 subgroups are constructed as infrastructure of knowledge technology, software supporting systems, R\&D activities \& improvement, security of knowledge. Under the main title of "External factors" 4 subgroups are constructed as customer relations, market conditions, supplier relations, legal institutions \& regulations. The hierarchical expression of the problem is expressed in the Figure 1.

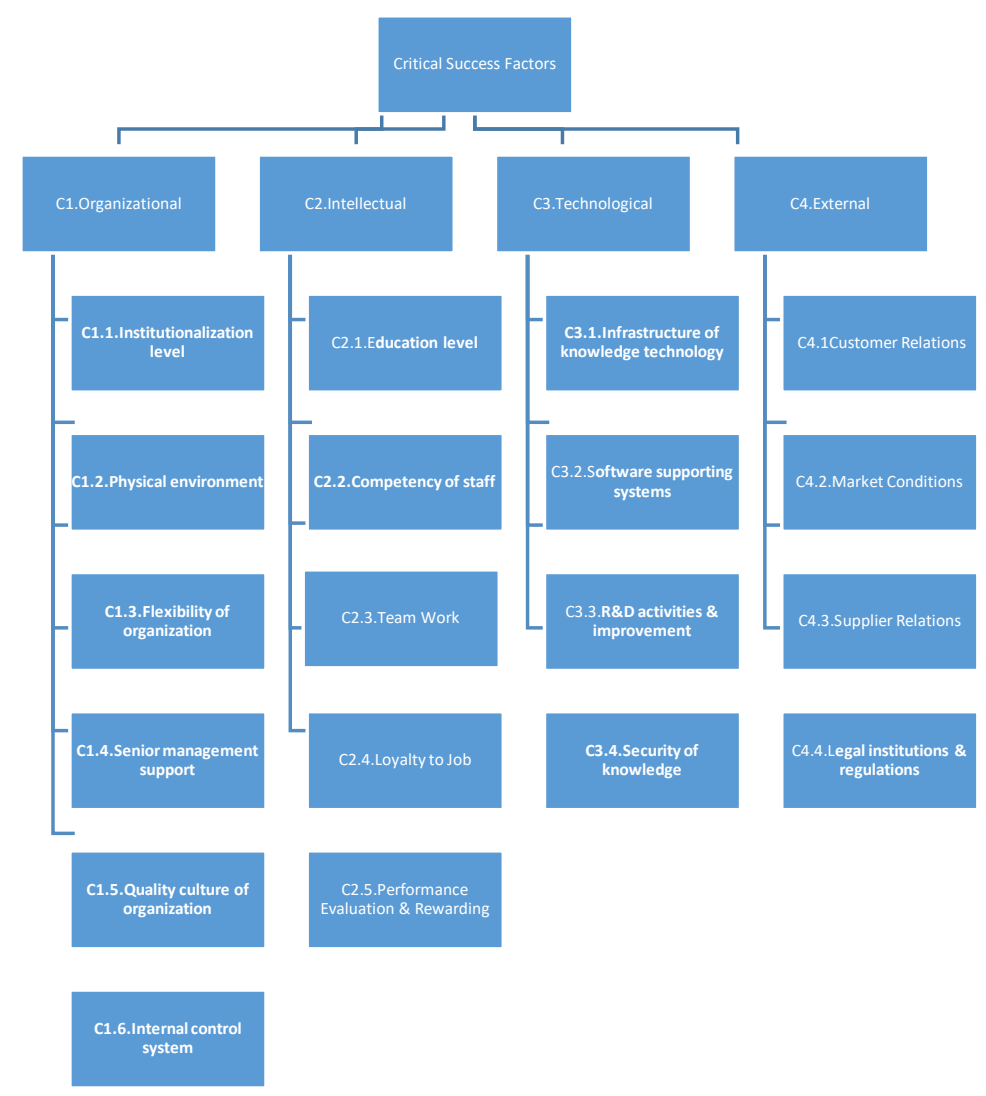




\section{Methodology}

\section{Decision Making with Fuzzy AHP}

In AHP method it is aimed to weight the criteria and the alternatives of a problem in order to make a decision with mathematical modelling of the thoughts, choices, and experiences of experts by expressing the problem in a hierarchical structure (Kahraman, 2018, p.293-297). Moreover fuzzy theory that is added to multi criteria decision making approach facilitates modelling the linguistic variables in human brain better than the classical methods with more success in coping with the vagueness. Using a committee of experts with a separate assessment and an aggregation operator of those separate choices within the mathematical model also helps to handle the problem in multi view perspective. There are various kinds of fuzzy AHP algorithms, improved from the first versions from 1980s like van Laarhoven-Pedrycz and Bucley algorithms. Those improvements are based on the selection of alternatives by using the fuzzy set theory and hierarchical analysis (Demirel et al., 2008). In this research Changs' fuzzy AHP algorithm that is based on the triangular fuzzy numbers and pairwise comparison scale is used (Chang, 1996, pp.649-655). In the AHP method the scale of 1-9 options is used with 1-3-5-7 represent the "just equal", "weakly important", strongly more important", "very strongly more important", "absolutely more important" The numbers 2-4-6-8 represents values between the lower and upper values (Bahadır et al, 2013-279-292) can be seen from Table 1. Also the reciprocal values form 1/ 9 to 1 are possible for the pairwise comparison scale (Saaty, 1995).

Table 1. Fuzzy Transformation Scale

\begin{tabular}{lll}
\hline Linguistic Scale & Triangular Fuzzy Scale & $\begin{array}{l}\text { Triangular Fuzzy } \\
\text { Reciprocal Scale }\end{array}$ \\
\hline Just Equal & $(1,1,1)$ & $(1 / 1,1 / 1,1 / 1)$ \\
\hline Weakly important & $(2,3,4)$ & $(1 / 4,1 / 3,1 / 2)$ \\
\hline Strongly more Important & $(4,5,6)$ & $(1 / 6,1 / 5,1 / 4)$ \\
\hline Very Strong more Important & $(6,7,8)$ & $(1 / 8,1 / 7,1 / 6)$ \\
\hline Absolutely more important & $(8,9,9)$ & $(1 / 9,1 / 9,1 / 8)$ \\
\hline
\end{tabular}

Chang's fuzzy AHP algorithm consist of the following steps. 
Step 1. Construct the fuzzified decision matrix $A_{i j}$ with $a_{j i}=a_{i j}^{-1}$ by using the scale in Table 1.

$$
A_{i j}=\left[\begin{array}{ccc}
(1,1,1) & \cdots & a_{1 n} \\
\vdots & \ddots & \vdots \\
a_{n 1} & \cdots & (1,1,1)
\end{array}\right]
$$

The elements of matrix $A_{i j}$ are triangular fuzzy numbers as $a_{i j}=$ $\left(l_{i j}, m_{i j}, u_{i j}\right)$.

Step 2. Apply the operations in the Eqs 1-4.

$$
\begin{aligned}
& \sum_{j=1}^{m} M_{g,}^{j}=\left(\sum_{j=1}^{m} l_{j}, \sum_{j=1}^{m} m_{j}, \sum_{j=1}^{m} u_{j}\right) \\
& \sum_{i=1}^{n} \sum_{j=1}^{m} M_{g,}^{j}=\left(\sum_{i=1}^{n} l_{j}, \sum_{i=1}^{n} m_{j}, \sum_{i=1}^{n} u_{j}\right) \\
& {\left[\sum_{i=1}^{n} \sum_{j=1}^{m} M_{g}^{j}\right]^{-1}=\left(\frac{1}{\sum_{i=1}^{n} u_{i}}, \frac{1}{\sum_{i=1}^{n} m_{i}}, \frac{1}{\sum_{i=1}^{n} l_{i}}\right)} \\
& S_{i}=\sum_{j=1}^{m} M_{g}^{j}, \otimes\left[\sum_{i=1}^{n} \sum_{j=1}^{m} M_{g}^{j}\right]^{-1}
\end{aligned}
$$

Hence the obtained $S_{i}$ are the fuzzy synthesis values for each DMs.

\section{Aggregation of Group Decisions}

There are so many aggregation operations. In this research the geometric mean operation is used, formula is given in the Eq. 5 (Lin, 2020).

$$
l_{i j}=\left(\prod_{k=1}^{K} l_{i j k}\right)^{1 / K}, m_{i j}=\left(\prod_{k=1}^{K} m_{i j k}\right)^{1 / K}{ }_{,} u_{i j}=\left(\prod_{k=1}^{K} u_{i j k}\right)^{1 / K}
$$

\section{Defuzzification}

There are various kinds of defuzzification operations. In this research centroid method derived from Yager (1981) is used and its formula is given the Eq. (6).

$$
w_{i}=\frac{S i_{l}+S_{i m}+S_{u}}{3} \quad i=1, \ldots, n
$$

\section{Normalization}

The normalization formula is given in the Eq. (7) which enables to make the sum of the weights equal to 1 .

$$
N w_{i}=\frac{w_{i}}{\sum_{i=1}^{n} w_{i}} \quad i=1, \ldots, n
$$




\section{Application of Fuzzy AHP on Critical Success Factors}

The main critical success factors and their sub-criteria that affect quality factors in AIS is determined as in Figure 1.

The pairwise comparison matrices for three experts on main criteria of the problem are given in the Eqs (8).

$$
\begin{aligned}
& A_{1}=\left[\begin{array}{cccc}
(1,1,1) & (1 / 4,1 / 3,1 / 2) & (1 / 7,1 / 6,1 / 5) & (2,3,4) \\
(2,3,4) & (1,1,1) & (1 / 4,1 / 3,1 / 2) & (4,5,6) \\
(5,6,7) & (2,3,4) & (1,1,1) & (7,8,9) \\
(1 / 4,1 / 3,1 / 2) & (1 / 6,1 / 5,1 / 4) & (1 / 9,1 / 8,1 / 7) & (1,1,1)
\end{array}\right] \\
& A_{2}=\left[\begin{array}{cccc}
(1,1,1) & (2,3,4) & (1 / 4,1 / 3,1 / 2) & (1,1,1) \\
(1 / 4,1 / 3,1 / 2) & (1,1,1) & (1 / 6,1 / 5,1 / 4) & (1,1,1) \\
(2,3,4) & (4,5,6) & (1,1,1) & (1,1,1) \\
(1,1,1)) & (1,1,1) & (1,1,1) & (1,1,1)
\end{array}\right] \\
& A_{3}=\left[\begin{array}{cccc}
(1,1,1) & (1 / 8,1 / 7,1 / 6) & (1 / 7,1 / 6,1 / 5) & (3,4,5) \\
(6,7,8) & (1,1,1) & (1 / 8,1 / 7,1 / 6) & (6,7,8) \\
(5,6,7) & (6,7,8) & (1,1,1) & (7,8,9) \\
(1 / 5,1 / 4,1 / 3)) & (1 / 8,1 / 7,1 / 6) & (1 / 9,1 / 8,1 / 7) & (1,1,1)
\end{array}\right]
\end{aligned}
$$

Then Chang Algorithm applied to each matrix and the fuzzy weights of each critera is found then the aggregation operation is applied. Obtained weights can be seen from Table 2 .

Table 2. The Fuzzy Weights of Main Criteria According to Each DM and Fuzzy Weight of Group Decision

\begin{tabular}{lcccc}
\hline & DM1 & DM2 & DM3 & Fuzzy Weight \\
\hline C1.Qrganisational & $(0.06,0.13,0.21)$ & $(0.14,0.21,0.31)$ & $(0.09,0.12,0.17)$ & $(0.09,0.15,0.22)$ \\
\hline C.2.Entellectual & $(0.13,0.28,0,42)$ & $(0.08,0.10,0.13)$ & $(0.26,0.34,0.45)$ & $(0.14,0.21,0.29)$ \\
\hline C.3.Technological & $(0.26,0.54,0.77)$ & $(0.37,0.56,0.82)$ & $(0.38,0.50,0.66)$ & $(0.33,0.53,0.75)$ \\
\hline C.4.External & $(0.03,0.05,0.69)$ & $(0.11,0.13,0.16)$ & $(0.03,0.03,0.04)$ & $(0.04,0.06,0.17)$ \\
\hline
\end{tabular}

The pairwise comparison of sub criteria and the calculated fuzzy weights of the criteria according to the group decision are given in the Table 3. 
Table 3. Aggregated Fuzzy Weights of Sub Criteria

\begin{tabular}{cccccccc}
\hline \multicolumn{2}{c}{ C1 } & C2 & & C 3 & C4 \\
\hline C1.1 & $(0.06,0.09,0.13)$ & C2.1 & $(0.06,0.08,0.13)$ & C3.1 & $(0.11,0.16,0.24)$ & C4.1 & $(0.13,0.19,0.27)$ \\
\hline C1.2 & $(0.03,0.05,0.07)$ & C2.2 & $(0.17,0.26,0.37)$ & C3.2 & $(0.16,0.24,0.35)$ & C4.2 & $(0.05,0.07,0.10)$ \\
\hline C1.3 & $(0.09,0.13,0.18)$ & C2.3 & $(0.14,0.21,0.31)$ & C3.3 & $(0.10,0.13,0.19)$ & C4.3 & $(0.13,0.20,0.27)$ \\
\hline C1.4 & $(0.12,0.17,0.25)$ & C2.4 & $(0.11,0.20,0.31)$ & C3.4 & $(0.21,0.33,0.50)$ & C4.4 & $(0.36,0.49,0.75)$ \\
\hline C1.5 & $(0.15,0.23,0.36)$ & C2.5 & $(0.08,0.11,0.16)$ & & & & \\
\hline C1.6 & $(0.18,0.26,0.37)$ & & & & & & \\
\hline
\end{tabular}

The pairwise comparison of sub criteria and the calculated fuzzy weights of the criteria according to the group decision are given in the Table 3.

Fuzzy weights of sub criteria are multiplied by the global weights of the main criteria then the defuzzification rule is applied. The importance degree are given in the Table 4.

Table 4. Weights of Main Criteria and Sub Criteria

\begin{tabular}{llllllll}
\hline \multicolumn{2}{c}{$\mathrm{C} 1=15 \%$} & $\mathrm{C} 2=22 \%$ & \multicolumn{3}{c}{$\mathrm{C} 3=54 \%$} & $\mathrm{C} 4=9 \%$ & \\
\hline $\mathrm{C} 1.1$ & 0,02 & $\mathrm{C} 2.1$ & 0,02 & $\mathrm{C} 3.1$ & 0,09 & $\mathrm{C} 4.1$ & 0,02 \\
\hline $\mathrm{C} 1.2$ & 0,01 & $\mathrm{C} 2.2$ & 0,06 & $\mathrm{C} 3.2$ & 0,14 & $\mathrm{C} 4.2$ & 0,01 \\
\hline $\mathrm{C} 1.3$ & 0,02 & $\mathrm{C} 2.3$ & 0,05 & $\mathrm{C} 3.3$ & 0,07 & $\mathrm{C} 4.3$ & 0,02 \\
\hline $\mathrm{C} 1.4$ & 0,03 & $\mathrm{C} 2.4$ & 0,05 & $\mathrm{C} 3.4$ & 0,19 & $\mathrm{C} 4.4$ & 0,05 \\
\hline $\mathrm{C} 1.5$ & 0,04 & $\mathrm{C} 2.5$ & 0.08 & & & & \\
\hline $\mathrm{C} 1.6$ & 0.04 & & & & & & \\
\hline
\end{tabular}

According to the results the "organizational factors" has importance degree of $15 \%$, The "intellectual factors" has importance degree of $22 \%$, "technological factors" has importance degree of $54 \%$, "external factors" has importance degree of $9 \%$.

According to the committee of DMs the most important sub criteria is C3.4 "Security of knowledge" with the weight $19 \%$. Secondly C.3.2 "Software supporting systems" with weight $14 \%$ is important. Thirdly C3.3. "R\&D activities and improvement" with weight $8 \%$.

\section{Conclusion}

Group decision is modelled with Fuzzy AHP on the relative importance of Critical Success Factors. The method enables to use qualitative criteria, with 
more success to cope with vagueness as well as the practically usage of linguistic transformation scale. The comparison of the weights that are constructed from the group decision with the weights that are constructed by a single DM decision in (Mizrahi et al., 2020: 1407-1414) can be seen from the Figure 2 and Figure 3.

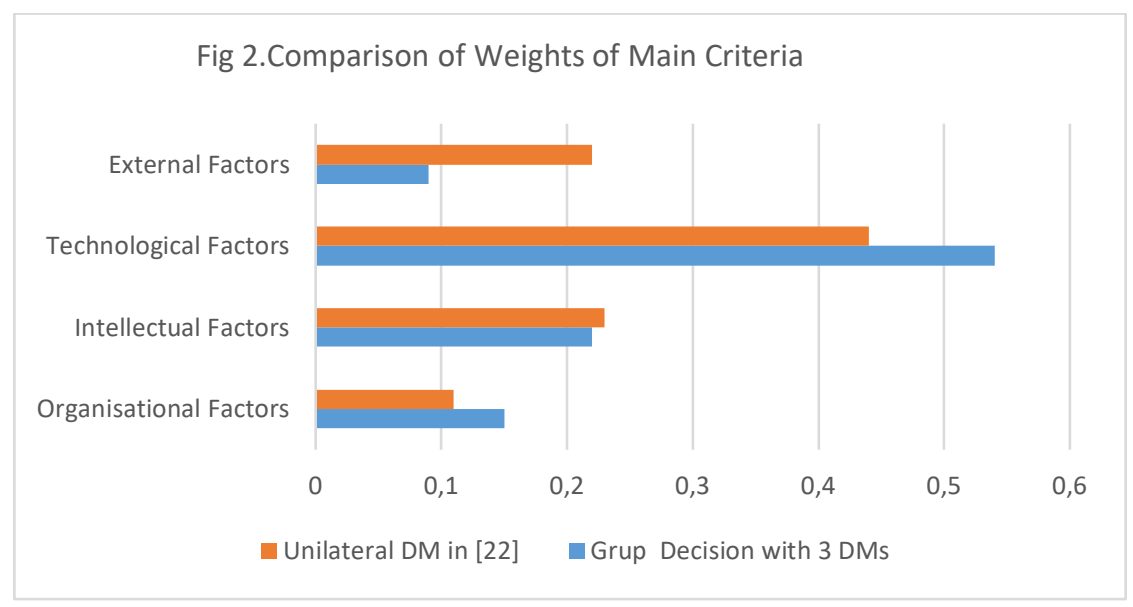

According to Figure 2, the weights of external factors and intellectual factors are decreased with the group decision while the other weights are increased. Moreover the prioritization of main criteria was technological factors, intellectual factors, external factors and organizational factors respectively in Lin (2020). According to group decision in this research the prioritization of main criteria are technological factors, intellectual factors, organizational factors and external factors respectively.

According to group decision of DMs; the most important main criteria is found to be the technological factor. In addition to this result, it is observed that the relative importance of intellectual and organizational factors follow the technological factor. The necessary technology investments first must be made to provide quality accounting information. The allocation of the necessary budget for the purchase of these technologies has been defined as the most important quality factor. Intellectual factors are the second most important main criteria in determining the quality of accounting information. In this context, it would be extremely beneficial for the enterprise to invest in the 
training and development of its employees. According to group of DMs external factors have less effect on the quality of accounting information.

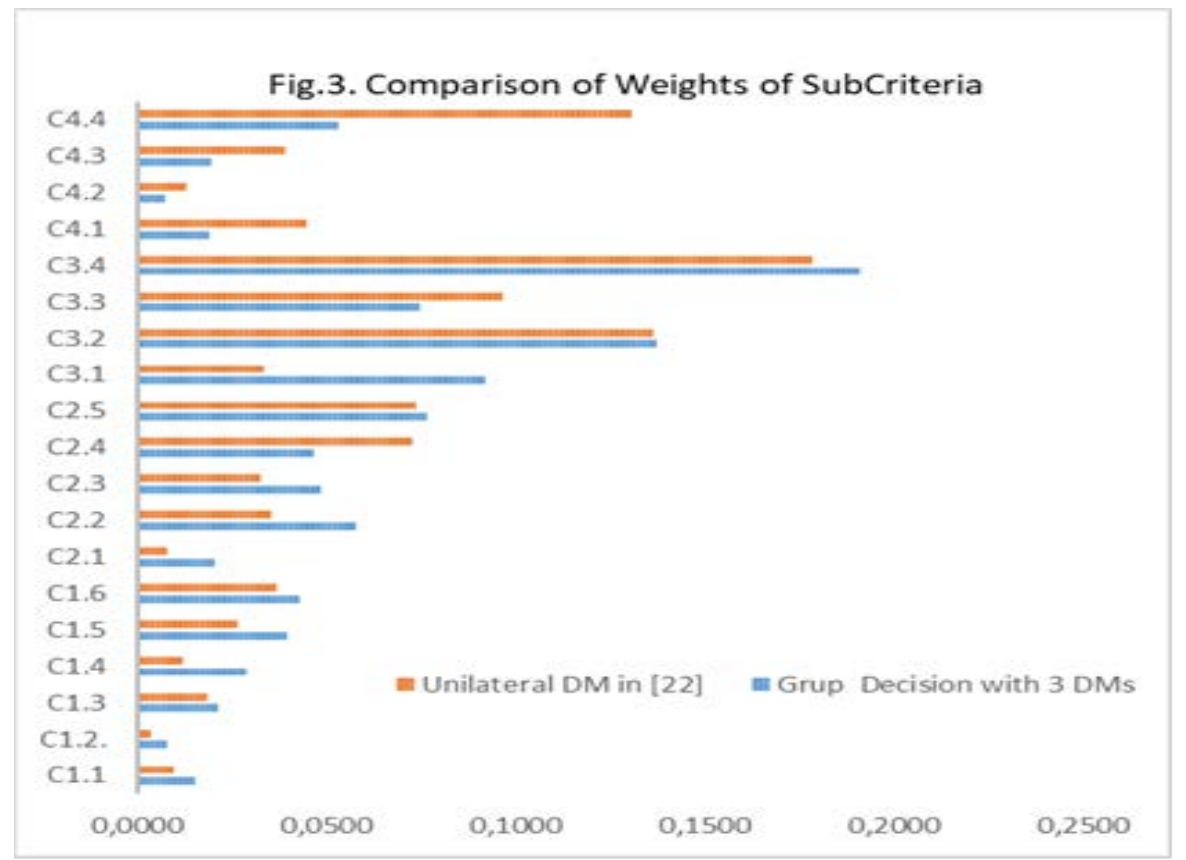

According to Figure 3 the relative importance degree of the sub criteria C2.4, C3.3, C4.1 ,C4.2, C4.3, C4.4 has decreased while the others has increased when compared with $\operatorname{Lin}(2020)$.

According to results the most important sub-criteria for group of DMs are security of knowledge, software supporting systems and legal institutions and regulations. According to this result, it is critical to establish and control the information security infrastructure of the system in AIS in enterprises. Making the necessary investments to increase the efficiency of software support systems is the second important sub-criterion that will affect the quality of the output to be produced from the system. Considering these factors in the investment plans of the managers, making the necessary technological investments will increase the information quality of AISs and increase the efficiency of the system. 
Legal Institutions and regulations have been identified as the third critical success factor determining the quality of information in AISs. Although external factors are the main criteria with the least impact, legal Institutions and regulations under external factors have been identified as the third critical sub-criteria determining the quality of information in AISs. Because financial accounting information produced in AIS is directly affected by changing legal regulations and accounting practices.

Group decision of experts in Accounting branch empowered or changed some of the results of the unilateral DM's decisions in Lin (2020). This is the advantage of Group decision with fuzzy AHP against the single DM. The qualitative criteria are easy modelled in the fuzzy AHP by using the pairwise comparison scale and Linguistic transformation of judgments of DMs to fuzzy numbers.

\section{References}

Acar, D. and Özçelik, H.(2011). Critical success factors that affect the quality of information which is produced by accounting information systems. The Journal of Accounting and Finance, 49, 10-23.

Bahadır, S.K., Çebi,S., Kahraman, C. and Kaloğlu, F.(2013). Developing a smart clothing system for blinds based on information axiom. International Journal of Computational Intelligence Systems, 6(2), 279-292.

Bullen, V.C. and Rockard, J.F.(1981). A primer on critical success factors, center for information system research working paper (1220-81). Sloan School of Management, Massachussets Institute of Technology.

Büyüközkan, G. and Feyzioğlu, O.(2004). A fuzzy-logic-based decision- making approach for new product development. Int. J. Production Economics, 90, 27-45.

Chang, D.Y.(1996). Applications of the extent analysis method on fuzzy AHP. European Journal of Operational Research, 95(3), 649-655.

Çukacı, Y.C.(2005). The evaluation of information as an economic value in terms of business and general economy. Eastern Anatolia Region Studies, 3(3), 11-19. 
Demirel, T., Çetin-Demirel, N. and Kahraman, C.(2008). Fuzzy analytical hierarchy process and its application. In Fuzzy Multi-Criteria Decision Making: Theory and Applications with Recent Developments. (Ed. C. Kahraman), Springer.

Dinç, E. and Abdioğlu, H.(2009). Relationships between corporate governance and accounting information systems on businesses: An empirical research on ISE- 100 Companies, Balkesir University The Journal of Social Sciences Institute, 12(21), 157-184.

Ergin, H.(1997). Strategic management accounting. Kütahya: Nadir Publishing House.

Jiao, F.(2016). Risk assessment and control for accounting information system based on fuzzy analytic hierarchy process. Eighth International Conference on Measuring Technology and Mechatronics Automation, 11-12 March 2016, Makao China, 580-583.

Kahraman, C.(2018). A brief literature review on fuzzy AHP. International Journal of the Analytic Hierarchy Process, 10(2), 293 -297.

Karagül, A.A.(2005). Information management, corporate source planning and accounting education in the perspective of accounting information systems. XXIV. Accounting Education Symposium Proceedings Book, 59-87.

Karahan, M.(2020). The relationship between pricing strategies and accounting information quality in tourism enterprises. International Journal of Society Researches, 15(26), 4664-4685.

Keskin, D.F.(2020). A fuzzy integrated approach for resilient supply chain network design problem. Süleyman Demirel University Journal of Vizyoner, 11(28), 770-789.

Lin, C.H.(2020). Optimal Core Operation in Supply Chain Finance Ecosystem by Integrating the Fuzzy Algorithm and Hierarchical Framework, International Journal of Computational Intelligence Systems, 13(1), 259-274.

Meixner, O.(2009). Fuzzy AHP group decision analysis and tts application for the evaluation of energy sources. Vienna, Austria: Institute of Marketing and Innovation.

Mizrahi,R., Tektaş, K., and Karakul-Kayahan, A. (2020). A. Fuzzy AHP based prioritization and taxonomy of information quality factors in accounting information systems. In Intelligent and Fuzzy Techniques: Smart and Innovative Solutions. Proceedings of the INFUS 2020 Conference, Istanbul, Turkey, July 21-23, Springer, (2020), 1407-1414. 
Rockard, J.F.(1979). Chiefexecutives define their own data needs. Harward Business Review, 57(2), p.81.

Rockard, J.F.(1982). The changing role of the information systems executive: a critical success factors perspective. Sloan Management Review, 24(1), 1-33.

Saaty, T.L.(1995). Decision making for leaders. the analytic hierarchy process for decisions in a complex World. Pittsburgh: RWS Publications.

Sagedhi, A., Azar, A., and Rad, R.S.(2012). Developing a fuzzy group AHP model for prioritizing the factors affecting success of high-tech SME's in Iran: A Case Study. Procedia - Social and Behavioral Sciences, 62, 957-961.

$\mathrm{Xu}, \mathrm{H}$., Koronios, A. and Brown, N.(2002). Managing data quality in accounting information systems. Idea Group Inc.

Yager, R.R.(1981). A procedure for ordering fuzzy subsets of the unit interval. Information Sciences, 24 (2), 143-161.

\section{Kaynakça Bilgisi / Citation Information}

Mizrahi, R., Tektaş, B. and Karakul A. (2021). Fuzzy multi criteria group decision for determining the relative importance of criticalsuccess factors in accounting information systems. OPUS-Uluslararass Toplum Araştırmaları Dergisi, 17(37), 4473-4486. DOI: 10.26466/opus. 869767 